\section{INFLUENCE OF SNOBBERY ON THE PRACTICE OF MEDICINE}

$\mathrm{T}$

HE lecture entitled "The Hand in Healing: a Study in Greek Medicine from Hippocrates to Ramazzini", delivered before the Royal Institution on December 4 by Prof. B. Farrington, professor of classics at University College, Swansea, has now been published by the Institution. In it Prof. Farrington discusses three topics: (1) the decline of anatomy and surgery after Galen; (2) the limitation of ancient medicine to the rich and the professional classes; (3) the invasion of medical science by a priori philosophical concepts. His object is to show that the decline in social status of the manual labourer (a) prevented the development of physics and chemistry, and $(b)$ caused a gradual deterioration of anatomy and surgery. That chemistry and physics, in the modern sense, were practically unknown, that surgery after Galen was separated from medicine and rapidly declined, are admitted truths; the novelty in Farrington's paper is his finding the cause of these phenomena in the Greek dislike of what were called "banausic" occupations. This is a most ingenious suggestion, almost certainly containing an element of truth. The evidence, however, should be closely examined before the hypothesis is accepted; in a few places Prof. Farrington appears to have misunderstood it.

The meaning of "banausic occupations" raises a thorny question. "Banausia" seems to have been an Athenian conception, appreciated perhaps throughout Greece but to a less degree than at Athens. It signifies not so much a prejudice against manual work in itself-for full honour was given to painters, sculptors, soldiers and farmers-but only against wearying trades involving long hours in conditions that ruin the worker's physique and dull his intellect. Moderns feel a similar prejudice against certain monotonous operations in factories. Such pursuits are harmful ; we are learning that "banausic" work should be done by machines rather than by men and women. The dislike of the Greeks was the result of a healthy instinct, but they are to be blamed because while accepting the facts they relegated "banausic" labour so far as possible to slaves, in order to have the leisure to live full lives as citizens. The first man to interest himself in occupational disease was apparently Paracelsus, who wrote a treatise on the ailments of miners. Be all this as it may, it would be difficult to show that medicine or even surgery was ever ranked among the "banausic" arts ; by the time surgery came to be despised, the Greek ideals that gave rise to "banausia" had ceased to exist.

On p. 15 Prof. Farrington states that "the Hippocratic medicine was already (fifth century B.c.) limited in its application to a section of the people", that is, to the idle rich. Yet medical historians such as Rossignol (in 1858), Littré and Couch (in 1934) have pointed out that the patients of the Hippocratic clinical histories are for the most part humble folk, being indeed often slaves. This fact has to be reconciled with Plato's statement that for slaves there were slave doctors.

Prof. Farrington also takes the view that the long treatise "Regimen" was a medical text-book written by a typical Hippocratic physician for general use. This is extremely doubtful. It was probably the work of a professional trainer, who with a special purpose wrote for a special public-those who, fearing lest their work should be interrupted by a threatened illness, wished to 'nip it in the bud'. To call such people valetudinarians (p. 17) is perhaps unfair.

The intrusion of speculative philosophy into medicine, vigorously attacked by the author of "Ancient Medicine", appears, if we may judge from the subsequent literature, never to have had much effect on actual medical practice. Every art, in addition to the practical theory that explains and reinforces it, has beyond this a speculative background of theory pure and simple. This speculation has a useful part to play, the classic example being Manson's guess that mosquitoes are connected with malaria, a guess that led to the discoveries of Ross. In the infancy of science it tended to encroach upon practical theory, so that the author of "Ancient Medicine" felt bound to protest. Greek thought, in fact, was over-rich in this intelligent guesswork, throwing out suggestion after suggestion in wild profusion. We moderns on the other hand are prone to undervalue it, although every now and then a Jeans or an Eddington inspires us with restrained and beautiful speculation. On the whole, however, we confine such thought to fiction. We should not like to read $\mathrm{H}$. G. Wells's fascinating theories in a textbook.

On p. 28 of Prof. Farrington's lecture we read: "almost two thousand years after Aristotle . . . was explicitly formulated ... the belief in the existence of definite bodies capable of being isolated . . . and recombined into new compounds". The latter half of this sentence would surely be a good description of the atomistic hypothesis of Democritus !

Even if these criticisms be justified, Prof. Farrington's lecture is of great value, and must certainly be taken into account by historians of Greek thought. W. H. S. Jones.

\section{THE GAS RESEARCH BOARD}

$\mathrm{T}$

HE Gas Research Board, which is supported by the Institution of Gas Engineers, the Society of British Gas Industries, and other bodies and individuals in the British gas industry, has recently issued its second report*. War-time conditions have prevented publication of some of the research done under its auspices and also the holding of the normal autumn research meeting.

The thirty-second report of the Refractory Materials Joint Committee*, which is also published, records, among other subjects, experiments on the materials used in the manufacture of firebacks for open coke fire-grates. Reference is made to the advantages in heating efficiency and performance of the use of the insulating refractory firebricks which have been so extensively developed in recent years.

Two reports, issued by the Gas Research Fellows for the year 1939-40 and 1941, deal with properties of Bunsen flames-in particular with flame ignition and propagation. There are two methods of measuring flame velocity: (a) the static method whereby propagation through a stationary explosive mixture is measured photographically; and $(b)$ when the velocity is calculated from the form and size of the stationary inner cone of a Bunsen flame and the known rate of gas mixture fed to the burner. Hitherto results have shown great discordance, which has

* (1) Communication G.R.B. No. 4. Pp. 16. (2) Communication G.R.B. No. 5. Pp. 92. (London: Gas Research Board, 1941.) 